\title{
The 2019 paroxyms at Stromboli volcano (Italy): timescales of eruption triggering.
}

\author{
C. M. Petrone*1, F. Di SteFano ${ }^{2}$, S. Mollo ${ }^{2,3}$, R.

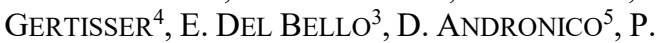 \\ SCARLATO $^{3}$
}

${ }^{1}$ The Natural History Museum, London, UK; c.petrone@nhm.ac.uk

${ }^{2}$ Sapienza-Universita Roma, Roma, Italy

${ }^{3}$ INGV-Roma, Roma, Italy

${ }^{4}$ Keele University, Staffordshire, UK

${ }^{5}$ INGV-Catania, Catania, Italy

Stromboli volcano (Southern Italy) shows characteristic persistent volcanic activity consisting of periodic discrete mild Strombolian explosions alternating with episodic lava effusions and more violents explosive events (parosysms), occuring at intervals of a few years. However, the two most recent paroxysms occurred at very short time interval, on 3 July and 28 August 2019, are challenging our understading of the most recent magma dynamics and related paroxysms.

Black scoriaceous lapilli and bombs, representing a degassed highly porphyritic $(h p)$ magma are typically ejected during the normal Strombolian eruptions. Episodic paroxysms also erupt black scoriaceous bombs and spatters, variably mingled with a small volume of light pumices, representing a more mafic, hotter, volatile-rich magma with low phenocryst content $(l p)$. These typical mingled $h p$-lp products, comprising plagioclase, clinopyroxene and minor olivine, were also erupted during the 2019 paroxysms. Clinopyroxene presents chemical heterogeneties similar to previously erupted products with diopsidic (Mg\# 81-90) and augitic (Mg\# 71-80) compositions. Diopsidic compositions are mostly recorded by rims and antecrystic cores, inherited from a mush region, and are markers of the more primitive, recharge lp-magmas. Augitic compositions are typical of clinopyroxenes cores representing the resident $h p$-magma.

Clinopyroxenes indicate a magmatic system hotter ( $l p$ magma $1160-1190^{\circ} \mathrm{C}$; $h p$-magma $1140-1170{ }^{\circ} \mathrm{C}$ ) than that of 2003-2017 activity. The paucity of antecrysts and the prevalence of diopsidic rims are the main and significant textural differences compared with previous 2003-2017 eruptions. Timescales of mafic triggering events (1-39 days) are clearly recorded by the diopsidic rims in the 2019 light pumices and mingled products, contrary to previous paroxysms. All this suggests fast and continuos inputs of $l p$ magmas, triggering paroxysms at a very short time intervals, perhaps in a rejuvinated magmatic system where the crystal mush has been disrupted and partly reduced. 